\title{
STEROIDS IN THE TREATMENT OF CHRONIC DISEASES
}

\author{
SHARMA P, IMAM S, MEHTA DK*
}

Department of Pharmaceutical Chemistry, MM College of Pharmacy, Maharishi Markandeshwar (Deemed to be University), Ambala, Haryana, India. Email: dkmehta17@rediffmail.com

Received: 11 April 2019, Revised and Accepted: 24 May 2019

\begin{abstract}
Since their identification, which was almost 80 years ago, steroids have played a prominent role in the treatment of many disease states such as chronic obstructive pulmonary disease, asthma, rheumatoid arthritis, and inflammatory bowel disease. Many of the clinical roles of steroids are related to their potent anti-inflammatory and immune-modulating properties. Numerous skin diseases are successfully treated with systemic steroids. Corticosteroids, though they are lifesaving drugs, produce adverse reactions which may be mild or life threatening. Steroids have diverse effects on various systems of the body. Therefore, educational interventions among physician, patients, as well as students should be carried out to further enhance rational drug use. The purpose of this review was to identify the most commonly prescribed steroids and their side effects, basic pharmacology, complications, as well as the assessment of patient knowledge about the use of steroids in tertiary care teaching hospitals.
\end{abstract}

Keywords: Corticosteroids, Disease, Rational, Side effects, Steroids.

(C) 2019 The Authors. Published by Innovare Academic Sciences Pvt Ltd. This is an open access article under the CC BY license (http://creativecommons. org/licenses/by/4. 0/) DOI: http://dx.doi.org/10.22159/ajpcr.2019.v12i7.3354b

\section{INTRODUCTION}

Steroids such as corticosteroids as well as androgenic steroids have a wide range of application in immunological, pulmonary, oncological, inflammatory, and dermatological diseases. Traditional teaching suggests that corticosteroids should be avoided during acute infectious episodes for fear of compromising the immune response [1].

The term steroid is relevant to a wide range of molecules showing varying physiological effects [2]. In respiratory, corticosteroids are used to treat acute exacerbations of chronic obstructive pulmonary disease (COPD) as well as uncontrolled asthma. They are also used in the treatment of hypersensitivity pneumonitis and immune-mediated vasculitis [3]. Anabolic steroids are used by athletes and bodybuilders to enhance their performance. Anabolic steroids history can be traced before the term steroid was even used as early as the 1930s. A synthetic form of testosterone (a male hormone) created by a team of scientist in the 1930s which helped to treat men who were unable to produce enough of the hormones for normal development, growth, and sexual functioning [4]. Initially, anabolic steroids were used by bodybuilders, but due to its positive effects, it became widely used in other sports also such as football, hockey, swimming, volleyball, wrestling, soccer, and cycling [5]. The misuse of anabolic steroids started in 1954 Olympics by professional athletes when Russian weightlifters were given testosterone [6].

Corticosteroids and their biologically active synthetic derivatives differ in their metabolic (glucocorticoid) and electrolyte-regulating (mineralocorticoid) activities.

Since their discovery in the 1940s, corticosteroids have become one of the most widely used and effective treatments for various inflammatory and autoimmune disorders. They are used as replacement therapy in adrenal insufficiency (at physiologic doses) as well as in supraphysiologic doses for the management of various dermatologic, ophthalmologic, rheumatologic, pulmonary, hematologic, and gastrointestinal (GI) disorders. In the field of respirology, systemic corticosteroids are used for the treatment of acute exacerbations of COPD and severe, uncontrolled asthma, as well as for inflammatory parenchymal lung diseases such as hypersensitivity pneumonitis and immune-mediated vasculitis [7].
Inappropriate use of corticosteroids may lead to over or under treatment [8], worsening of conditions, or eventually therapy failure. Patients may refuse to take corticosteroids because they fear their unwanted, documented side effects (e.g., hyperglycemia, osteoporosis, weight gain, etc.) [9]. According to the American College of Clinical Pharmacy, the clinical pharmacist has an important role to play in patient education and promotion of patient adherence [10].

Hence, the clinical pharmacist's intervention has a positive impact in identifying and managing chronic diseases among patients.

This review focuses on the classification and functions of steroids and risks associated with their supplementation in chronic diseases. The purpose of this review was to identify the most commonly prescribed steroids in chronic diseases and their side effects, basic pharmacology, complications, as well as the assessment of patient knowledge about the use of steroids in tertiary care teaching hospitals.

\section{CLASSIFICATION OF STEROIDS}

There are two different types of steroids present in the body. The first group is corticosteroids and the second group is androgenic/anabolic steroid [11].

\section{Adrenal cortex}

Three groups of hormones are produced by adrenal cortex. These hormones are synthesized from cholesterol in the adrenal glands and gonads. Glucocorticoids, mineralocorticoids, and androgens (sex hormones) hormones are referred to as corticosteroids (adrenocorticoids) [12].

\section{Glucocorticoids}

Glucocorticoids are further classified on the basis of duration of action as follows:

- Short-acting glucocorticoids

- Intermediate-acting glucocorticoids

- Long-acting glucocorticoids.

The stimulation of adrenocorticotropic hormone from the anterior pituitary secretes glucocorticoids and it is also secreted by stress. The main glucocorticoids include cortisol and corticosterone. Cortisol 
is synthesized from cholesterol in reticularis and zona fasciculata of adrenal cortex [12]. Cortisol helps in the regulation of many metabolic processes such as synthesis of glucose from amino acids and fatty acids and in liver glycogen deposition [13].

The functions of glucocorticoids include:

- Glycogenesis promotion

- Gluconeogenesis promotion

- Decrease in protein synthesis

- In adipose tissue increased lipolysis

- Increased reabsorption of sodium and water from the renal tubules [12].

Glucocorticoids are more commonly prescribed for their antiinflammatory and immunosuppressive properties [11].

\section{Mineralocorticoids}

Mineralocorticoids primarily act on the kidney, where they cause sodium and water retention and active excretion of potassium and protons. The primary mineralocorticoid is aldosterone, but other endogenous hormones such as progesterone and deoxycorticosterone have mineralocorticoid function. Aldosterone is synthesized exclusively in the zona glomerulosa region of the adrenal cortex. The production of aldosterone is influenced by sodium level in blood.

The main function includes:

- Control reabsorption of sodium by the renal tubules

- $\quad$ Potassium excretion [12].

\section{Androgens/anabolic steroids}

Anabolicsteroidsare man-made or synthetic modification oftestosterone which is a male sex hormone. These compounds are collectively known as anabolic/androgenic steroids. The term "Androgenic" means male sex characteristics and "Anabolic" means muscle building. Anabolic androgenic steroids (AASs) can be administered in different forms such as oral, intramuscular injection, parenteral, and transdermal [14]. Anabolic steroids are of two types, i.e., 17 alpha alkyl derivatives (e.g., oxandrolone, oxymetholone, and fluoxymesterone) and 17-beta ester derivatives (e.g., testosterone cypionate, testosterone enanthate, and nandrolone decanoate). Nandrolone phenpropionate was one of the first anabolic steroids used by professional athletes as a doping agent in 1960 [15-17].

The main function includes:

- Endogenous androgen is responsible for secondary sex characteristics

- Growth and development of male sex organs $[18,19]$

\section{CORTICOSTEROIDS: SYNTHESIS, SECRETION, AND} BIOAVAILABILITY

Corticosteroids consist of glucocorticoids and mineralocorticoids which are steroid hormones, synthesized, and released by the adrenal gland in response to physiological changes and stress [20]. Glucocorticoids, when released from the adrenal gland into the blood circulation, access target tissues to regulate physiologic processes such as metabolism, skeletal growth, cardiovascular function, and reproduction and immune function. Glucocorticoids play the physiological and pharmacological functions which are mediated by the intracellular glucocorticoid receptor (GR). The GR consists of three fundamental domains: An $\mathrm{N}$ terminal transactivation domain, a central deoxyribonucleic acid (DNA)-binding domain, and a C-terminal ligand-binding domain [21]. Mineralocorticoids such as aldosterone help in the regulation of sodium concentration in the body $[22,23]$.

\section{GLUCOCORTICOIDS: PHYSIOLOGICAL EFFECT}

\section{Metabolism}

Glucocorticoid such as cortisol helps in the regulation of carbohydrate, nucleic acid, lipid, and protein metabolism. The process of gluconeogenesis by the liver is stimulated by cortisol which results in increased concentration of blood glucose level [24-26]. In the metabolic system, cortisol is involved in the reduction of protein stores which is stored in all body cells, except for liver. The main reason for this is increased catabolism of protein already in the cell and decreased protein synthesis [24,25,27].

\section{Anti-inflammatory effects}

A large amount of cortisol shows anti-inflammatory effects. It stabilizes lysozyme membrane and decreases the release of lysozymes which causes inflammation and results in a decrease in capillary permeability preventing loss of plasma proteins into tissues [24-26,28].

\section{Bone and calcium metabolism}

Glucocorticoids inhibit the function of osteoblast which results in osteopenia and osteoporosis which is the characteristic of the excess level of glucocorticoids [24,25]

\section{Blood pressure control}

Blood pressure increased by glucocorticoids involves a variety of mechanisms which includes action on kidney and vasculature. The sensitivity to pressor agents such as angiotensin-2 and catecholamines is increased in the vascular smooth muscle, while the endothelial dilation mediated by nitric oxide is reduced $[24,25,28]$.

\section{Central nervous system and mood}

While observing the patients clinically with glucocorticoid excess and deficiency reveals that the brain is an important target for glucocorticoids with euphoria, apathy,depression, lethargy, and psychosis are being important manifestations [24,26].

\section{Developmental changes}

Plasma cortisol is required in the last trimester of pregnancy in the progression of a variety of systems that are important in extrauterine life for the survival of the fetus. These systems involve maturation of various enzymes in the liver, pulmonary surfactant production $[24,25]$.

\section{Gut}

The risk of developing peptic ulcer disease is increased by chronic administration of glucocorticoids and in patients with glucocorticoid excess, pancreatitis with fat necrosis is observed [24-26].

\section{MECHANISM OF ACTION OF STEROIDS}

Corticosteroids after entering into the cell bind to cytosolic receptors which are responsible for transportation of steroids into the nucleus. The steroid receptor complex binds to glucocorticoid response elements or mineralocorticoid-specific elements and alters gene expression [29].

\section{Glucocorticoids}

Glucocorticoid hormones show anti-inflammatory and immunosuppressive effects. Its mechanism involves a decline in antibody production and a decrease in white blood cells count such as a number of lymphocytes, basophils, and eosinophils which ultimately decrease the number of T-lymphocytes. This results in the gradual destruction of lymphoid tissue which leads to inhibition of normal immune response. The Primary effect of glucocorticoids are mentioned in (Table 1). The major immunosuppressive effect of glucocorticoids appears to be the modulation of the production of cytokines through

\section{Table 1: Primary effect of glucocorticoids [31]}

Anti-inflammatory: Inhibits inflammation by blocking the action of inflammatory mediators or by inducing anti-inflammatory mediator Immunosuppressive: Directly affects T-lymphocytes and suppress delayed hypersensitivity reactions Antiproliferative: Inhibition of DNA synthesis and epidermal cell turnover

Vasoconstrictive: Inhibits histamine action and other vasoconstrictive mediators DNA deoxyribonucleic acid

DNA: Deoxyribonucleic acid 
inhibition of nuclear factor B expression and nuclear translocation. The cytokines are released from immunocompetent cells which mediate both the phases of inflammation, i.e., acute and chronic and then involve in controlling the immune response. Glucocorticoids also show antiallergic properties [30].

\section{Mineralocorticoids}

Renin, an enzyme secreted by kidney cells when there occurs a reduction in renal blood flow. As a result, the angiotensinogen (produced by the liver) is converted into angiotensin which stimulates aldosterone production by the adrenal cortex. Aldosterone further leads to reabsorption of sodium and water and excretion of potassium by the kidneys. This results in increase in blood volume and blood flow through the kidneys, suppressing the production of renin and secretion of aldosterone [12].

\section{Androgens}

Androgens bind to a specific nuclear receptor in a target cell. In muscle and liver, testosterone acts as active ligand, but in other tissues, it must be metabolized to dihydrotestosterone (DHT) derivatives. Testosterone is converted to DHT by enzyme 5-alpha-reductase after diffusing into the cells of seminal vesicles, prostate, epididymis, and skin. After that, it binds to the receptor. Testosterone is biotransformed to estradiol in the brain. The synthesis of specific ribonucleic acids (RNAs) and proteins is stimulated by the hormone/receptor complex which binds to DNA [32].

\section{STEROIDS ARE PRESCRIBED IN CHRONIC DISEASES}

The commonly prescribed steroids in chronic diseases and their side effects are mentioned in (Table 2).

\section{Chronic obstructive pulmonary disease}

COPD is a multidimensional disease with a variety of intermediate and clinical phenotypes [33]. It is estimated that COPD will become the third most common cause of death worldwide by 2030 [34-36]. The Global Initiative for Chronic Obstructive Lung Disease defined COPD as "a common preventable and treatable disease characterized by persistent airflow limitation that is usually progressive and associated with an enhanced chronic inflammatory response in the airway and the lung to noxious particles or gases. Exacerbations and comorbidities contribute to the overall severity in individual patient" [37]. The pulmonary injury involves three stages, i.e., initiation (due to exposure to cigarette smoking, pollutants, and infectious agents), progression, and consolidation [33]. Symptoms including breathlessness decreased the quality of life (QOL) and loss of lung function become worst with acute exacerbations of COPD [38,39]. COPD is associated with chronic bronchitis and emphysema. The British Medical Research Council defined chronic bronchitis as "daily productive cough for at least 3 consecutive months for more than 2 successive years" [40]. The treatment of COPD includes smoking cessation and pulmonary rehabilitation. Besides, this other treatment consists of bronchodilators in the early stage and oxygen in the late stage. Short courses of systemic corticosteroids often along with antibiotics have been used since decades to treat inflammation and exacerbations. However, their side effects made them unsuitable to treat long-term stable COPD. In the early 1980s, inhaled corticosteroids were given to the patient diagnosed with asthma as well as COPD in combination with long-acting $\beta$-agonist. The inhaled form of corticosteroids proved to be highly effective in the treatment of COPD and asthma [41].

\section{Asthma}

Asthma is a respiratory condition which consists of increased airway hyperresponsiveness and increased episodes of obstruction and inflammation of airway and tissue remodeling [42]. It is observed that the prevalence of asthma has been increased rapidly over the past few decades and it is estimated that there are 334 million sufferers of asthma worldwide. The disease is expected to develop over the next $15-20$ years $[43,44]$. Asthma is characterized by recurrent episodes of cough, wheezing, and breathlessness which can be resolved after using bronchodilator medication [45]. Corticosteroid was first used in 1956 to treat acute asthma exacerbation. Corticosteroids such as prednisone that have less mineralocorticoid activity and dexamethasone that have no mineralocorticoid activity became more attractive therapies to treat asthma. In 1972, Clark discovered the effect of inhaled beclomethasone in the treatment of asthma with fewer side effects than systemic steroids [46]. Inhaled corticosteroids are the most commonly used treatment for asthma which can suppress the characteristic inflammation in airways [47].

Table 2: Commonly prescribed steroids in chronic diseases

\begin{tabular}{|c|c|c|c|}
\hline Generic name & Trade name & Dosage & Side effects, risks \\
\hline \multicolumn{4}{|l|}{ COPD } \\
\hline Prednisolone [58] & Orapred, Pediapred & $30-40 \mathrm{mg}$ & $\begin{array}{l}\text { Acne, weight gain, increased appetite, menstrual period } \\
\text { changes, mood changes }\end{array}$ \\
\hline Prednisone [59] & Deltasone & $30-40 \mathrm{mg}$ & $\begin{array}{l}\text { Loss of appetite, increased sweating, weakness, } \\
\text { abdominal pain }\end{array}$ \\
\hline Budesonide & Pulmicort & $400-1000 \mu \mathrm{g} /$ day & Pneumonia, cataract, diabetes, glaucoma \\
\hline Salbutamol & Proventil, Ventolin & Neb - 2.5-5 mg $[60,61]$ & $\begin{array}{l}\text { Shaking of arms and feet, irregular heartbeat, sleep } \\
\text { disturbance, skin rash, and spotting }\end{array}$ \\
\hline Ipratropium bromide & Atrovent & $\mathrm{Neb}-0.5 \mathrm{mg}[60,61]$ & Flu-like symptoms, nervousness, dry mouth, headache \\
\hline Terbutaline & Terbulin & $\mathrm{Neb}-5-10 \mathrm{mg}$ & Tremor, nervousness, palpitation, dizziness, headache \\
\hline \multicolumn{4}{|r|}{ - } \\
\hline Salbutamol [62] & Proventil, Ventolin & $\mathrm{Neb}-2.5 \mathrm{mg}$ & $\begin{array}{l}\text { Shaking of arms and feet, irregular heartbeat, sleep } \\
\text { disturbance, skin rash, and spotting }\end{array}$ \\
\hline Methyl prednisolone & Medrol & $80 \mathrm{mg} /$ day & Upset stomach, vomiting, depression \\
\hline Hydrocortisone & Enzone & $400 \mathrm{mg} /$ day & Redness, swelling, bruising, joint pain, itching \\
\hline \multicolumn{4}{|r|}{ 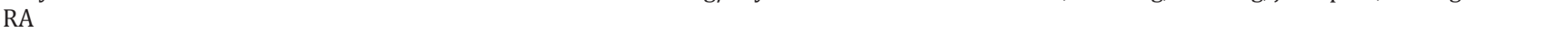 } \\
\hline Methyl prednisolone & Depo-Medrol, Medrol & $40-80 \mathrm{mg}$ per $\mathrm{ml}[54,63]$ & $\begin{array}{l}\text { High prevalence of fractures, adrenal insufficiency, } \\
\text { lowered bone mineral density }\end{array}$ \\
\hline Prednisolone & Orapred, Pediapred & $2.5-15 \mathrm{mg}$ & $\begin{array}{l}\text { Increased susceptibility of infection, cataract formation, } \\
\text { cutaneous atrophy, increased risk of fracture }[64,65]\end{array}$ \\
\hline \multicolumn{4}{|r|}{ 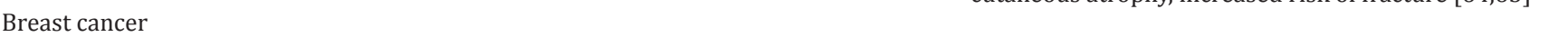 } \\
\hline NPP [66] & Durabolin & $25-50 \mathrm{mg} / \mathrm{ml}$ & Acne, increased hair growth, voice changes [67] \\
\hline Nandrolone decanoate & Deca-Durabolin & $25-50 \mathrm{mg}$ & $\begin{array}{l}\text { Acne, increased hair growth, voice changes, increased } \\
\text { sexual desire }\end{array}$ \\
\hline
\end{tabular}

COPD: Chronic obstructive pulmonary disease, RA: Rheumatoid arthritis, NPP: Nandrolone phenylpropionate 


\section{Rheumatoid arthritis}

Rheumatoid arthritis (RA) is an autoimmune disease which affects nearly $1 \%$ population all over the world [48]. It is characterized by inflammation of synovial and destruction of a joint which can cause severe disability if left untreated [49]. It mainly affects the small joints of hands and feet. It is a chronic inflammatory disease which causes pain, swelling, and stiffness. The disease has no cure yet. Symptomatic treatment can be given to the patients suffering from RA which can increase the QOL. Treatment includes disease-modifying antirheumatic drugs, nonsteroidal anti-inflammatory drugs, and low-dose steroids [50-52]. Glucocorticoids have the ability to reduce signs and symptoms in inflammatory disorders; therefore, they are widely used to treat RA [53]. Prednisone is an important drug which is used to treat different kinds of inflammatory conditions including RA [54].

\section{Breast cancer}

Breast cancer is the type of cancer that originates from breast tissues, mostly from the inner lining of milk ducts or the lobules that supply the ducts with milk. Breast cancer is life threatening and found to be the most common cause of cancer in women. Worldwide, breast cancer is the fifth most common cause of cancer death and comprises $10.4 \%$ of all cancer incidences in women. The possibility of breast cancer is 100 times more in women than in men. Cancer cells have similar DNA and RNA (but not identical) to the cells of the organism from which they are originated [55]. AASs are commonly prescribed in the management of various pathological conditions including breast cancer, hereditary angioedema, renal insufficiency, and endometriosis [56]. The hormonal therapy for breast cancer includes tamoxifen, toremifene, and fulvestrant [57]

\section{Adverse drug effects of steroid supplementation \\ Long-term effect}

These effects include - osteoporosis, fractures, osteonecrosis, weight gain, hyperglycemia, cataract, glaucoma, cardiovascular disease, dyslipidemia, myopathy, psychiatric and cognitive disturbance, immunosuppression, and growth and adrenal suppression also observed in children, increased risk of infections, decrease in bone density, ulcers/GI bleeding, thin skin, bruise easily, and slower healing of wounds $[68,69]$.

\section{Short-term effect}

These effects includes - skin rash, swelling, hot flush, abdominal discomfort, upper respiratory tract infections, spinal conditions, allergies, acne, sepsis, venous thromboembolism, insomnia and sleep disturbances, gastric irritation, sodium and fluid retention, increased appetite and weight gain, and mood changes - agitation and emotional lability $[70,71]$.

\section{COMMON SIDE EFFECTS OF STEROIDS}

\section{Steroids induced osteoporosis}

The mostcommon side effect with long-term use of glucocorticoid is bone loss [72]. However, the most significant effect of glucocorticoids in bone is an inhibition of bone formation [73-77]. Patient receiving high dose of glucocorticoid is at greater risk of developing bone loss as compared to patient taking lower dose of the drug. Thus, glucocorticoid-induced bone loss is dose dependent [78-81]. The treatment of glucocorticoidinduced bone loss includes decreasing the dose of glucocorticoid, calcium and Vitamin D supplementation, and pharmacologic therapy to increase bone density and prevent further bone loss [82]. The dose of glucocorticoid and duration of glucocorticoid therapy should be as low as possible because even low dose of glucocorticoid therapy can decrease bone mineral density [83].

\section{Steroids induced hyperglycemia}

Steroids are considered to be the main cause of drug-induced hyperglycemia [84]. The mechanism includes their interference with signaling cascades in muscle cells, which leads to reduction in insulinmediated glucose uptake and synthesis of glycogen $[85,86]$. Due to variations in dose of steroids and the scheme used, the hyperglycemia approach should always be individualized [87]. A complete evaluation of the degree of glucose intolerance, the patient condition, the degree of hyperglycemia, the dose, frequency, and mechanism of corticosteroid compound must be made to derive the best therapeutic outcome and determine the best treatment approach in each patient [88]

\section{Steroids induced weight gain}

Another side effect with long-term ( $\geq 3$ months) use of corticosteroids includes weight gain [89] with prolonged use of prednisone (1.7-5.8 kg), prednisolone (1.5-4.4 kg), and cortisone (1.5-8.4 kg). These drugs are associated with significant weight gain [90-95]. There exists considerable variability in the amount of weight gain that patient will experience while taking corticosteroids [96]. However, very few alternatives are available for corticosteroids. The change in treatment regimen can be helpful in decreasing the incidence of weight gain in patients. Prednisone can be given in alternate day dosing schedule as it can also promote weight loss and reduce weight gain [97].

\section{Gastrointestinal disease}

GI side effects include candidiasis, pancreatitis, peptic ulcer disease, and GI hemorrhage. Glucocorticoid has shown to increase risk of peptic ulceration and GI bleeding, this effect could be due to concomitant use of nonsteroidal anti-inflammatory drugs [98-100]. Glucocorticoid users have shown another GI complication, i.e., acute pancreatitis [101]. However, glucocorticoid use cannot be considered as etiological agent in causing acute pancreatitis which is shown by recent study [102].

\section{Cardiovascular disease and dyslipidemia}

Glucocorticoid uses are known to cause higher cardiovascular risk, including hypertension, hyperglycemia, and obesity. Myopathy generally occurs over several weeks to months of glucocorticoid use. Proximal muscle weakness and atrophy in both the lower and upper extremities are typically present in patients $[103,104]$.

\section{ROLE OF PHARMACIST'S COUNSELING}

The management programs of various diseases are usually fulfilled in a hospital setting and by physicians. However, community pharmacist holds their expertise on various medication and interaction with the patients regarding counseling and prescription refill. Therefore, they could also contribute their effective role in the management of diseases. They could assist asthma and COPD patients to maintain their condition and to decrease disease complications. A pharmacist could provide suitable information about medications and the proper use of inhalers. They could also ask the patients about their understanding toward disease and medications, explaining the importance of inhaled corticosteroids, provide knowledge to the patient regarding potential side effects of inhaled corticosteroids, and facilitate medication adherence [105-108]. The effect of pharmacist care on asthma patients has been investigated only by a few welldesigned studies [109-114]. Community pharmacies can provide an effective platform for cost-effective treatment and health-related QOL in COPD [115-118]. The abuse of topical corticosteroid (TC) has now become a global issue $[119,120]$. Pharmacists are the key to address the problem of TC abuse due to a lack of patient awareness of TC use, especially in India. This problem arises because, as compared to qualified specialist, patients have easy access to the pharmacist in the pharmacy $[121,122]$.

\section{DISCUSSION}

Corticosteroids, though they are lifesaving drugs, produce adverse reactions which may be mild or life threatening. Steroids have diverse effects on various systems of the body. Therefore, educational interventions among physician, patients, as well as students should be carried to further enhance rational drug use. Community pharmacist holds their expertise on various medication and interaction with the patients regarding counseling and prescription refill. Therefore, they could also contribute their effective role in the management of diseases. 
Hence, establishing standard guidelines for prescribers for treating any acute and chronic diseases, where steroids necessary is highly warranted.

\section{CONCLUSION}

Corticosteroids are widely used in the treatment of various autoimmune and inflammatory diseases. In this article, we have focused on chronic diseases, in which steroids are commonly prescribed. Despite the benefits of these agents, their long-term use is highly associated with potentially serious adverse effects affecting the GI tract, central nervous system, endocrine, musculoskeletal, and cardiovascular system. The effects of steroid use can vary widely, and the full spectrum of side effects can be present even in patients taking low doses.

Most of the side effects can be minimized through careful patient monitoring, instructions regarding the proper use of inhalers, following preventive measures including the use of lowest effective dose and lower potency agents required to treat various disease conditions.

Strategies regarding lifestyle modification should be advised to the patient to improve their QOL.

The clinical pharmacist's intervention has a positive impact on identifying and managing chronic diseases among patients. Such intervention decreases patient's fear and increases compliance with corticosteroid treatment plan. Education of the general public through media programs and the introduction of continuing medical education programs for medical, paramedical personnel, and pharmacists are probably the most important steps to be taken to create awareness of the hazards of misuse of corticosteroids.

\section{ACKNOWLEDGMENT}

I am highly indebted to MM College of Pharmacy and Maharishi Markandeshwar (Deemed to be University) University management for the valuable guidance and constant supervision for supporting to complete this review.

\section{CONFLICTS OF INTEREST}

The author declares that we did not have the conflicts of interest for collecting the information of compiling this article and also for the paper publication

\section{REFERENCES}

1. Meikle AW, Tyler FH. Potency and duration of action of glucocorticoids. Effects of hydrocortisone, prednisone and dexamethasone on human pituitary-adrenal function. Am J Med 1977;63:200-7.

2. Kendall EC, Reichstein T, Hench SP. The development of cortisone as a therapeutic agent. Indian Med J 1951;45:239-41.

3. Woods JA, Wheeler JS, Finch CK, Pinner NA. Corticosteroids in the treatment of acute exacerbations of chronic obstructive pulmonary disease. Int J Chron Obstruct Pulmon Dis 2014;9:421-30.

4. Buckley WE, Yesalis CE $3^{\text {rd }}$, Friedl KE, Anderson WA, Streit AL, Wright JE. Estimated prevalence of anabolic steroid use among male high school seniors. JAMA 1988;260:3441-5.

5. Basaria S, Wahlstrom JT, Dobs AS. Clinical review 138: Anabolicandrogenic steroid therapy in the treatment of chronic diseases. J Clin Endocrinol Metab 2001;86:5108-17.

6. Wade N. Anabolic steroids: Doctors denounce them, but athletes aren't listening. Science 1972;176:1399-403.

7. Jacobsen RP, Pincus G. The chemistry of adrenal steroids. Symposium on the adrenal gland. Am J Med 1951;10:531-3

8. Saag KG, FurstDE, BarnesPJ. Major SideEffects of Inhaled Glucocorticoids. In: Basow DS, editor. UpToDate. Waltham, MA: UpToDate; 2011. p. 31.

9. Joseph J. What is Corticosteroid Phobia? Contact Magazine News; 2013. p. 102-15.

10. Schweiger TA, Zdanowicz M. Systemic corticosteroids in the treatment of acute exacerbations of chronic obstructive pulmonary disease. Am J Health Syst Pharm 2010;67:1061-9.

11. Brunton LL, Chabner BA, Knollmann BC. Androgens. Goodman \& Gilman's the Pharmacological Basis of Therapeutics. 12 $2^{\text {th }}$ ed., Ch. 41.
New York: McGraw Hill Education; 2007. p. 1804-10.

12. Godkar PB, Godkar DP. Hormones. Textbook of Medical Laboratory Technology. $3^{\text {rd }}$ ed., Ch. 1. Mumbai: Bhalani Publishing House; 2014. p. $570-1$

13. Altschule MD, Tillotson KJ. The use of testosterone in the treatment of depressions. N Engl J Med 1948;239:1036-8.

14. Frati P, Busardò FP, Cipolloni L, Dominicis ED, Fineschi V. Anabolic androgenic steroid (AAS) related deaths: Autoptic, histopathological and toxicological findings. Curr Neuropharmacol 2015;13:146-59.

15. Lusetti M, Licata M, Silingardi E, Bonsignore A, Palmiere C. Appearance/Image- and performance-enhancing drug users: A forensic approach. Am J Forensic Med Pathol 2018;39:325-9.

16. Jones IA, Togashi R, Hatch GF, Weber AE, Vangsness CT. Anabolic steroids and tendons: A review of their mechanical, structural and biologic effects. J Orthop Res 2018;26:250-7.

17. Armstrong JM, Avant RA, Charchenko CM, Westerman ME, Ziegelmann MJ, Miest TS, et al. Impact of anabolic androgenic steroids on sexual function. Transl Androl Urol 2018;7:483-9.

18. Melo Junior AF, Dalpiaz PLM, Sousa GJ, Oliveira PWC, Birocale AM, Andrade TU, et al. Nandrolone alter left ventricular contractility and promotes remodelling involving calcium-handling proteins and reninangiotensin system in male SHR. Life Sci 2018;208:239-45.

19. Zhou S, Glowacki J. Dehydroepiandrosterone and bone. Vitam Horm 2018;108:251-71.

20. Miller WL, Auchus RJ. The molecular biology, biochemistry, and physiology of human steroidogenesis and its disorders. Endocr Rev 2011;32:81-151.

21. Kumar R, Thompson EB. Gene regulation by the glucocorticoid receptor: Structure: Function relationship. J Steroid Biochem Mol Biol 2005;94:383-94.

22. Gomez-Sanchez EP. Brain mineralocorticoid receptors: Orchestrators of hypertension and end-organ disease. Curr Opin Nephrol Hypertens 2004;13:191-6.

23. Sakai RR, Nicolaïdis S, Epstein AN. Salt appetite is suppressed by interference with angiotensin II and aldosterone. Am J Physiol 1986;251:R762-8

24. Vaz M, Raj T, Anura K. Adenocortical hormones. Guyton and Hall Textbook of Medical Physiology. $2^{\text {nd }}$ ed., Ch. 78. Philadelphia, PA: Saunders, Elsevier; 2016. p. 561-72.

25. Barrett KE, Barman SM, Boitano S, Brooks HL. Hormonal control of calcium and phosphate metabolism and the physiology of bone. In: Ganong WF, editor. Review of Medical Physiology. 24 ${ }^{\text {th }}$ ed., Ch. 21. New York: McGraw-Hill Medical; 2012. p. 377-80.

26. Tripathi KD. Essentials of Medical Pharmacology. $6^{\text {th }}$ ed., Ch. 32. New Delhi: Jaypee Brothers Medical Publishers (P) Ltd.; 2008. p. 660-5.

27. Bruton L, Lazo J, Parker K. Goodman \& Gilman's the Pharmacological Basis of Therapeutics. $11^{\text {th }}$ ed., Ch. 58. New York: McGraw Hill Education; 2006. p. 1573-86.

28. Braunwald E, Fauci AS, Kasper DL, Hauser SL, Longo DL, Jameson L, et al., editors. Harrison's Principles of Internal Medicine by Kasper. $17^{\text {th }}$ ed., Ch. 58. New York: McGrawHill; 2008. p. 1000-6.

29. Trevor AJ, Katzung BG, Kruidering-Hall M. Corticosteroids and antagonists. Pharmacology Examination and Board Review. $11^{\text {th }}$ ed., Ch. 39. New York: McGraw-Hill Education; 2015. p. 322-5.

30. Barnes PJ. Mechanisms and resistance in glucocorticoid control of inflammation. J Steroid Biochem Mol Biol 2010;120:76-85.

31. Halbert RJ, Natoli JL, Gano A, Badamgarav E, Buist AS, Mannino DM. Global burden of COPD: Systematic review and meta-analysis. Eur Respir J 2006;28:523-32.

32. Whalen K. Estrogens and androgens. In: Harvey RA, Champe PC, editors. Lippincott's Illustrated Reviews-Pharmacology. $4^{\text {th }}$ ed., Ch. 25. Philadelphia, PA: Lippincott Williams \& Wilkins; 2008. p. 308.

33. Tuder RM, Petrache I. Pathogenesis of chronic obstructive pulmonary disease. J Clin Invest 2012;122:2749-55

34. Mathers CD, Loncar D. Projections of global mortality and burden of disease from 2002 to 2030. PLoS Med 2006;3:e442.

35. Diaz-Guzman E, Mannino DM. Epidemiology and prevalence of chronic obstructive pulmonary disease. Clin Chest Med 2014;35:7-16.

36. Cheyne L, Irvin-Sellers MJ, White J. Tiotropium versus ipratropium bromide for chronic obstructive pulmonary disease. Cochrane Database Syst Rev2015;9:238-45.

37. Johnston AK, Mannino DM. Epidemiology of COPD exacerbations. In: Wedzicha JA, Martinez FJ, editors. Exacerbations of Chronic Obstructive Pulmonary Disease. Vol. 6. London: Informa Healthcare; 2008. p. 15-26.

38. Seemungal TA, Donaldson GC, Paul EA, Bestall JC, Jeffries DJ, 
Wedzicha JA, et al. Effect of exacerbation on quality of life in patients with chronic obstructive pulmonary disease. Am J Respir Crit Care Med 1998; 157:1418-22.

39. Vestbo J, Vogelmeier C, Small M, Higgins V. Understanding the GOLD 2011 strategy as applied to a real-world COPD population. Respir Med 2014;108:729-36.

40. Donaldson GC, Seemungal TA, Bhowmik A, Wedzicha JA. Relationship between exacerbation frequency and lung function decline in chronic obstructive pulmonary disease. Thorax 2002;57:847-52

41. Suissa S, Barnes PJ. Inhaled corticosteroids in COPD: The case against. Eur Respir J 2009;34:13-6.

42. Sarithamol S, Divya V, Sunitha VR, Suchitra S, Pushpa VL, Manoj KB. Genetic involvement of interleukin 4 for asthma and identification of potential phytochemical scaffold through molecular docking studies. Int J Curr Pharm Res 2018;10:45-57.

43. Holgate ST, Polosa R. Treatment strategies for allergy and asthma. Nat Rev Immunol 2008;8:218-30.

44. Ahmetaj LN. The Global Asthma Report 2014. Auckland, New Zealand: Global Asthma Network; 2014. p. 102-12.

45. Agarwal R, Dhooria S, Aggarwal AN, Maturu VN, Sehgal IS, Muthu V, et al. Guidelines for diagnosis and management of bronchial asthma: Joint ICS/NCCP (I) recommendations. Lung India 2015;32:S3-42.

46. Clark TJ. Effect of beclomethasone dipropionate delivered by aerosol in patients with asthma. Lancet 1972;1:1361-4.

47. Barnes PJ. How corticosteroids control inflammation: Quintiles prize lecture 2005. Br J Pharmacol 2006;148:245-54.

48. Alamanos Y, Drosos AA. Epidemiology of adult rheumatoid arthritis. Autoimmun Rev 2005;4:130-6.

49. Aletaha D, Neogi T, Silman AJ, Funovits J, Felson DT, Bingham CO $3^{\text {rd }}$, et al. 2010 rheumatoid arthritis classification criteria: An American College of Rheumatology/European League against rheumatism collaborative initiative. Ann Rheum Dis 2010;69:1580-8.

50. Baan H, Haagsma CJ, van de Laar MA. Corticosteroid injections reduce size of rheumatoid nodules. Clin Rheumatol 2006;25:21-3.

51. Aviña-Zubieta JA, Abrahamowicz M, De Vera MA, Choi HK, Sayre EC, Rahman MM, et al. Immediate and past cumulative effects of oral glucocorticoids on the risk of acute myocardial infarction in rheumatoid arthritis: A population-based study. Rheumatology (Oxford) 2013;52:68-75.

52. Caplan L, Russell AS, Wolfe F. Steroids for rheumatoid arthritis: The honeymoon revisited (once again). J Rheumatol 2005;32:1863-5.

53. Chandrappa M, Biswas S. Glucocorticoids in management of adult rheumatoid arthritis-current prescribing practices and perceptions of physicians in India: GLUMAR Survey. J Ancient Dis Prev Remedies 2017;7:220.

54. Krasselt M, Baerwald C. The current relevance and use of prednisone in rheumatoid arthritis. Expert Rev Clin Immunol 2014;10:557-71.

55. Sharma GN, Dave R, Sanadya J, Sharma P, Sharma KK. Various types and management of breast cancer: An overview. J Adv Pharm Technol Res 2010;1:109-26.

56. Saddick SY. The impact of nandrolone decanoate administration on ovarian and uterine tissues in rat: Luteinizing hormone profile, histopathological and morphometric assessment. Saudi J Biol Sci 2018;25:507-12.

57. Balentine JR. Improved survival in metastatic breast cancer. Int J Breast Cancer 2017;31:105-15

58. Suissa S, Dell'Aniello S, Ernst P. Long-term natural history of chronic obstructive pulmonary disease: Severe exacerbations and mortality. Thorax 2012;67:957-63

59. Lindenauer PK, Pekow PS, Lahti MC, Lee Y, Benjamin EM, Rothberg MB. Association of corticosteroid dose and route of administration with risk of treatment failure in acute exacerbation of chronic obstructive pulmonary disease. JAMA 2010;303:2359-67.

60. O'Driscoll R. Home nebulized therapy - is it effective? Respir Med 1991;85:1-3

61. Newhouse M, Dolovich M. Aerosol therapy: Nebulizer vs. metered dose inhaler. Chest 1987;91:799-800.

62. Kelly HW. Levalbuterol for asthma: A better treatment? Curr Allergy Asthma Rep 2007;7:310-4.

63. Lim SS, Conn DL. The use of low-dose prednisone in the management of rheumatoid arthritis. Bull Rheum Dis 2001;50:1-4

64. Cooper C, Coupland C, Mitchell M. Rheumatoid arthritis, corticosteroid therapy and hip fracture. Ann Rheum Dis 1995;54:49-52.

65. Caldwell JR, Furst DE. The efficacy and safety of low-dose corticosteroids for rheumatoid arthritis. Semin Arthritis Rheum 1991;21:11.

66. Elks J. The Dictionary of Drugs: Chemical Data: Chemical Data,
Structures and Bibliographies. Vol. 43. New York: Springer; 2014. p. 660-70.

67. William L. Anabolics. Mol Nutr Llc 2011;29:460-7.

68. Liu D, Ahmet A, Ward L, Krishnamoorthy P, Mandelcorn ED, Leigh $\mathrm{R}$, et al. A practical guide to the monitoring and management of the complications of systemic corticosteroid therapy. Allergy Asthma Clin Immunol 2013;9:30.

69. Eustice C. Corticosteroids for inflammation. Verywell Health 2018;36:112-8

70. Min KH, Rhee CK, Jung JY, Suh MW. Characteristics of adverse effects when using high dose short term steroid regimen. Korean J Audiol 2012;16:65-70.

71. Waljee AK, Rogers MA, Lin P, Singal AG, Stein JD, Marks RM, et al. Short term use of oral corticosteroids and related harms among adults in the United States: Population based cohort study. BMJ 2017;357:j1415.

72. Curtiss PH Jr., Clark WS, Herndon $\mathrm{CH}$. Vertebral fractures resulting from prolonged cortisone and corticotropin therapy. J Am Med Assoc 1954;156:467-9.

73. Adler RA, Rosen CJ. Glucocorticoids and osteoporosis. Endocrinol Metab Clin North Am 1994;23:641-54.

74. Canalis E. Clinical review 83: Mechanisms of glucocorticoid action in bone: Implications to glucocorticoid-induced osteoporosis. J Clin Endocrinol Metab 1996;81:3441-7.

75. Lukert BP, Raisz LG. Glucocorticoid-induced osteoporosis: Pathogenesis and management. Ann Intern Med 1990;112:352-64.

76. Manolagas SC, Weinstein RS. New developments in the pathogenesis and treatment of steroid-induced osteoporosis. J Bone Miner Res 1999; 14:1061-6.

77. Joshisree KP, Rajesh G, Siddarama R. Corticosteroid induced ecchymosis. Int J Pharm Pharm Sci 2018;10:211-3.

78. Reid IR, Heap SW. Determinants of vertebral mineral density in patients receiving long-term glucocorticoid therapy. Arch Intern Med 1990; $150: 2545-8$.

79. Pocock NA, Eisman JA, Dunstan CR, Evans RA, Thomas DH, Huq NL, et al. Recovery from steroid-induced osteoporosis. Ann Intern Med 1987;107:319-23.

80. van Staa TP, Leufkens HG, Abenhaim L, Zhang B, Cooper C. Oral corticosteroids and fracture risk: Relationship to daily and cumulative doses. Rheumatology (Oxford) 2000;39:1383-9.

81. Buckley LM, Leib ES, Cartularo KS, Vacek PM, Cooper SM. Effects of low dose corticosteroids on the bone mineral density of patients with rheumatoid arthritis. J Rheumatol 1995;22:1055-9.

82. Vermaat H, Kirtschig G. Prevention and treatment of glucocorticoidinduced osteoporosis in daily dermatologic practice. Int J Dermatol 2008:47:737-42.

83. Zelissen PM, Croughs RJ, van Rijk PP, Raymakers JA. Effect of glucocorticoid replacement therapy on bone mineral density in patients with Addison disease. Ann Intern Med 1994;120:207-10.

84. van Raalte DH, Ouwens DM, Diamant M. Novel insights into glucocorticoid-mediated diabetogenic effects: Towards expansion of therapeutic options? Eur J Clin Invest 2009;39:81-93.

85. Ruzzin J, Wagman AS, Jensen J. Glucocorticoid-induced insulin resistance in skeletal muscles: Defects in insulin signalling and the effects of a selective glycogen synthase kinase-3 inhibitor. Diabetologia 2005;48:2119-30.

86. Perez A, Jansen-Chaparro S, Saigi I, Bernal-Lopez MR, Miñambres I, Gomez-Huelgas R. Glucocorticoid-induced hyperglycemia. J Diabetes 2014;6:9-20.

87. Pichardo-Lowden AR, Fan CY, Gabbay RA. Management of hyperglycemia in the non-intensive care patient: Featuring subcutaneous insulin protocols. Endocr Pract 2011;17:249-60.

88. Trence DL. Management of patients on chronic glucocorticoid therapy: An endocrine perspective. Prim Care 2003;30:593-605.

89. Brown ES, Chandler PA. Mood and cognitive changes during systemic corticosteroid therapy. Prim Care Companion J Clin Psychiatry 2001:3:17-21.

90. Wung PK, Anderson T, Fontaine KR, Hoffman GS, Specks U, Merkel PA, et al. Effects of glucocorticoids on weight change during the treatment of Wegener's granulomatosis. Arthritis Rheum 2008;59:746-53

91. Stenson WF, Cort D, Rodgers J, Burakoff R, DeSchryver-Kecskemeti K, Gramlich TL, et al. Dietary supplementation with fish oil in ulcerative colitis. Ann Intern Med 1992;116:609-14

92. Hjelmesaeth J, Hartmann A, Kofstad J, Stenstrøm J, Leivestad T, Egeland $\mathrm{T}$, et al. Glucose intolerance after renal transplantation depends upon prednisolone dose and recipient age. Transplantation 1997;64:979-83. 
93. Gorard DA, Hunt JB, Payne-James JJ, Palmer KR, Rees RG, Clark ML, et al. Initial response and subsequent course of Crohn's disease treated with elemental diet or prednisolone. Gut 1993;34:1198-202.

94. McKenzie R, O’Fallon A, Dale J, Demitrack M, Sharma G, Deloria M, et al. Low-dose hydrocortisone for treatment of chronic fatigue syndrome: A randomized controlled trial. JAMA 1998;280:1061-6.

95. Chrousos GA, Kattah JC, Beck RW, Cleary PA. Side effects of glucocorticoid treatment. Experience of the optic neuritis treatment trial. JAMA 1993;269:2110-2.

96. Cheskin LJ, Bartlett SJ, Zayas R, Twilley CH, Allison DB, Contoreggi C. Prescription medications: A modifiable contributor to obesity. South Med J 1999;92:898-904.

97. Messer J, Reitman D, Sacks HS, Smith H Jr., Chalmers TC. Association of adrenocorticosteroid therapy and peptic-ulcer disease. N Engl J Med 1983;309:21-4.

98. Piper JM, Ray WA, Daugherty JR, Griffin MR. Corticosteroid use and peptic ulcer disease: Role of nonsteroidal anti-inflammatory drugs. Ann Intern Med 1991;114:735-40.

99. Gabriel SE, Jaakkimainen L, Bombardier C. Risk for serious gastrointestinal complications related to use of nonsteroidal antiinflammatory drugs. A meta-analysis. Ann Intern Med 1991;115:787-96.

100. Herrala J, Puolijoki H, Liippo K, Raitio M, Impivaara O, Tala E, et al. Clodronate is effective in preventing corticosteroid-induced bone loss among asthmatic patients. Bone 1998;22:577-82.

101. Kikuchi Y, Imakiire T, Yamada M, Saigusa T, Hyodo T, Kushiyama T, et al. Effect of risedronate on high-dose corticosteroid-induced bone loss in patients with glomerular disease. Nephrol Dial Transplant 2007;22:1593-600.

102. Moghadam-Kia S, Werth VP. Prevention and treatment of systemic glucocorticoid side effects. Int J Dermatol 2010;49:239-48.

103. Miller ML. Glucocorticoid-induced myopathy. UpToDate 2013;11:34-6

104. Horne R. Compliance, adherence, and concordance: Implications for asthma treatment. Chest 2006;130:65S-72S.

105. Boulet LP. Perception of the role and potential side effects of inhaled corticosteroids among asthmatic patients. Chest 1998;113:587-92.

106. Cochrane MG, Bala MV, Downs KE, Mauskopf J, Ben-Joseph RH. Inhaled corticosteroids for asthma therapy: Patient compliance, devices, and inhalation technique. Chest 2000;117:542-50.

107. Laforest L, Van Ganse E, Devouassoux G, Bousquet J, Chretin S, Bauguil G, et al. Influence of patients' characteristics and disease management on asthma control. J Allergy Clin Immunol 2006; 117:1404-10

108. Armour C, Bosnic-Anticevich S, Brillant M, Burton D, Emmerton L, Krass I, et al. Pharmacy asthma care program (PACP) improves outcomes for patients in the community. Thorax 2007;62:496-502.
109. Barbanel D, Eldridge S, Griffiths C. Can a self-management programme delivered by a community pharmacist improve asthma control? A randomised trial. Thorax 2003;58:851-4.

110. Mangiapane S, Schulz M, Mühlig S, Ihle P, Schubert I, Waldmann HC. Community pharmacy-based pharmaceutical care for asthma patients. Ann Pharmacother 2005;39:1817-22.

111. Saini B, Krass I, Armour C. Development, implementation, and evaluation of a community pharmacy-based asthma care model. Ann Pharmacother 2004;38:1954-60.

112.Schulz M, Verheyen F, Mühlig S, Müller JM, Mühlbauer K, KnopSchneickert E, et al. Pharmaceutical care services for asthma patients: A controlled intervention study. J Clin Pharmacol 2001;41:668-76.

113. Weinberger M, Murray MD, Marrero DG, Brewer N, Lykens M, Harris LE, et al. Effectiveness of pharmacist care for patients with reactive airways disease: A randomized controlled trial. JAMA 2002;288:1594-602

114. Wright D, Twigg M, Barton G, Thornley T, Kerr C. An evaluation of a multi-site community pharmacy-based chronic obstructive pulmonary disease support service. Int J Pharm Pract 2015;23:36-43.

115. Wei L, Yang X, Li J, Liu L, Luo H, Zheng Z, et al. Effect of pharmaceutical care on medication adherence and hospital admission in patients with chronic obstructive pulmonary disease (COPD): A randomized controlled study. J Thorac Dis 2014;6:656-62.

116.van Boven JF, Tommelein E, Boussery K, Mehuys E, Vegter S, Brusselle GG, et al. Improving inhaler adherence in patients with chronic obstructive pulmonary disease: A cost-effectiveness analysis. Respir Res 2014;15:66

117. Ottenbros S, Teichert M, de Groot R, Griens F, Sodihardjo F, Wensing M, et al. Pharmacist-led intervention study to improve drug therapy in asthma and COPD patients. Int J Clin Pharm 2014;36:336-44.

118. Kumar S, Goyal A, Gupta YK. Abuse of topical corticosteroids in India: Concerns and the way forward. J Pharmacol Pharmacother 2016;7:1-5.

119. Al Hawsawi K, Alaauldeen S, Albarnawi N, Mashrai H, Alosaimi R, Alsufyani $\mathrm{H}$, et al. Prevalence of misuse of topical corticosteroids among populations in Western region of Saudi Arabia. Int J Adv Res 2017;5:297-307.

120. Saraswat A, Lahiri K, Chatterjee M, Barua S, Coondoo A, Mittal A, et al. Topical corticosteroid abuse on the face: A prospective, multicenter study of dermatology outpatients. Indian J Dermatol Venereol Leprol 2011;77:160-6.

121. Nagesh TS, Akhilesh A. Topical steroid awareness and abuse: A Prospective study among dermatology outpatients. Indian J Dermatol 2016;61:618-21.

122. Ashique KT, Chandrasekhar D. Role of clinical pharmacist in cosmetovigilance of misuse and abuse of topical corticosteroids. Indian $\mathrm{J}$ Dermatol 2017;62:213 